\title{
A description of liver and blood changes in matrinxã (Brycon amazonicus) during induced spawning
}

\author{
Fábio S. Zanuzzo ${ }^{\mathrm{a}, *}$, Gustavo M. Oda ${ }^{\mathrm{a}}$, Marcio A. Hoshiba ${ }^{\mathrm{b}}$, José A. Senhorini ${ }^{\mathrm{c}}$, Sérgio F. Zaiden ${ }^{\mathrm{d}}$, \\ Elisabeth C. Urbinati ${ }^{\mathrm{a}, \mathrm{c}}$ \\ ${ }^{a}$ Universidade Estadual Paulista (UNESP), Centro de Aquicultura da Unesp, Via de Acesso Prof. Paulo Donato Castelane, 14.884-900 Jaboticabal, São Paulo, Brazil \\ ${ }^{\mathrm{b}}$ Universidade Estadual Paulista (UNESP), Via de Acesso Prof. Paulo Donato Castelane, 14.884-900 Jaboticabal, São Paulo, Brazil \\ ${ }^{c}$ Centro Nacional de Pesquisa e Conservação de Peixes Continentais (CEPTA/ICMBio). Rodovia Euberto Pereira de Godoy, km 6,5, 13630-000 Pirassununga, São Paulo, \\ Brazil \\ ${ }^{\mathrm{d}}$ Universidade de Rio Verde - FESURV, Campus Universitário, s/n., 75901-970 Rio Verde, Goiás, Brazil
}

\section{A R T I C L E I N F O}

\section{Keywords:}

Induced spawning

Hormonal therapy

Stress

Liver damage

Brycon amazonicus

\begin{abstract}
A B S T R A C T
We investigated the effects of induced spawning on liver and blood cell changes in matrinxã breeders, a commercially valuable South American fish that requires hormonal manipulation and stripping to spawn, a trait shared by other important aquaculture species. Little attention has been given to this topic despite the mortality rates commonly reported by fish farmers following this practice. In this study, we show that the overall handling required in induced spawning severely impaired the liver (hypertrophy of the hepatocytes, enlargement of the cell nuclei and reductions of glycogen deposits) which was mainly attributed to hormonal therapy. Additionally, the induced spawning procedure increased the number of red blood cells and decreased the white blood cell and thrombocyte count. These results corroborate the stressful conditions and immunosuppression, which together with the liver damage may explain the reported mortality rates. Finally, our findings outline important approaches for improving induced spawning technique.
\end{abstract}

\section{Introduction}

One of the most important steps in domestication and the creation of a sustainable aquaculture industry is the control of the reproductive processes of fish (Donaldson, 1996; Zohar and Mylonas, 2001). In captivity, the reproduction of some species can be easily controlled by environmental manipulation, while for other species, such procedures are impractical due to the complexity of the environmental stimulation required and a lack of information regarding their ecobiology (Mylonas et al., 2010). In these cases, hormonal therapy is necessary and has been used as an efficient tool for inducing maturation and viable fertilized eggs (Mylonas et al., 2010; Yaron, 1995; Zohar and Mylonas, 2001). This technique has been successfully used in several important aquaculture species, such as sturgeon (Acipenser spp.), carp (Cyprinus carpio), European catfish (Silurus glanis), Japanese catfish (Silurus asotus) pikeperch (Sander lucioperca), Japanese eel (Anguilla japonica) and salmonids (for review see (Mylonas et al., 2010)).

During induced spawning by hormone therapy, the fish are captured, transported, exposed to air and injected. In some species, it is also necessary to employ stripping, which may cause additional stress.
Although this technique has been applied in a wide range of species, surprisingly, the effects of the overall handling required to induce spawning on the breeders' health have been largely ignored, and the deleterious effects has been mainly empiric (Mylonas and Zohar, 2001) with limited information available (Khalil et al., 2012; Zanuzzo et al., 2015). Moreover, disease outbreaks and mortality in breeders following induced spawning are commonly reported by fish farmers. Breeders also represent an important asset for fish farmers because the building of the broodstock of some species may be very expensive depending on the time required to reach sexual maturity, even when genetically improved breeders are utilized. For example, the species examined in the study, the matrinxã (Brycon amazonicus), requires 2-3 years to reach sexual maturation, and the death of a single breeder represents a major loss.

In fish, the liver plays critical roles in various physiological processes, including digestion, metabolism, excretion, protein biosynthesis, endocrine function, energy storage, hormone clearance, and stress and immune responses (Faught and Vijayan, 2016; Karim et al., 2011; Moon, 2004). These functions combine with its position and the blood supply makes this organ the one most associated with health status and

\footnotetext{
* Corresponding author at: Department of Ocean Sciences, Memorial University of Newfoundland, St. John's A1C 5S7, Canada.

E-mail addresses: fabioszanuzzo@gmail.com, fabioz@mun.ca (F.S. Zanuzzo).
} 
detoxification (van der Oost et al., 2003). These features qualify the liver as the target organ to be investigated during the induced spawning procedure and, along with blood cell profiles, provide reliable indicators of health status.

Due to the lack of information about the effects of induced spawning on breeders' health and in an attempt to understand the reasons for disease outbreaks and mortality after this procedure, this study investigated liver and blood cell changes in breeders during induced spawning (here we asked whether overall handling to induce spawning affects the liver and hematological parameters). To this end, we used matrinxã fish, one of the most commercially valuable South American fish, especially in the Amazonian region. This species spawns once during its annual reproductive cycle and fits the definition of a singlebatch group-synchronous fishes that require artificial gamete collection and insemination.

\section{Material and methods}

\subsection{Broodstock management and experimental conditions}

The experiment was performed during the reproductive season (Nov to $\mathrm{Dec})$. We used 21 breeders $(858.3 \pm 25.2 \mathrm{~g}, 41.1 \pm 0.04 \mathrm{~cm}$; mean \pm SEM), and only fish in the advanced gonadal maturation stages were used. Firstly, the breeders were carefully captured in an earthen pond $(40 \mathrm{~m} \times 10 \mathrm{~m} \times 1.5 \mathrm{~m} ; \mathrm{L} \times \mathrm{W} \times \mathrm{D})$ using a dragging net. Then, twelve females were selected based on visual external characteristics, including a swollen abdomen, reddish urogenital papilla and a bulging coelomic cavity, and nine males were selected according to the color and fluidity of the sperm extruded after the application of gentle abdominal pressure. The selected fish were then separated by sex and transferred in two commercial transport boxes of 1000-L during 10 min to two 1500-L indoor tanks (a female tank and male tank) with continuously aerated water. Before placing the breeders into two indoor tanks, they were quickly anesthetized $\left(0.1 \mathrm{~g}^{-1} \mathrm{MS}-222\right.$, tricaine methanesulfonate; Sigma-Aldrich, São Paulo, SP, Brazil; " E10521), and weighed, measured and tagged using colored wire tags on the dorsal fin. This procedure is necessary to apply the accurate hormone therapy to induce spawning. The water parameters monitored during this period were: temperature $\left(25.8 \pm 0.1^{\circ} \mathrm{C}\right.$; mean \pm SEM), dissolved oxygen $\left(6.2 \pm 0.1 \mathrm{mgl}^{-1}\right.$; mean $\left.\pm \mathrm{SEM}\right)$, and $\mathrm{pH}(7.03 \pm 0.05$; mean \pm SEM). The photoperiod was $14 \mathrm{~h}$ light: $10 \mathrm{~h}$ dark (natural photoperiod and lights). The fish were fed a commercial diet in the indoor tanks at the same feeding ratio given in the earthen pond $(1.5 \%$ body weight daily) and remained in the conditions described above (indoor tanks) for 1 week prior to the induced spawning procedure.

\subsection{Experimental protocol: the effects of induced spawning}

After one week, six fish (three females and three males, $\mathrm{N}=6$ ) were sampled before induced spawning for assessments of the liver and complete blood cell count basal status (i.e., initial sampling/witness). Following spawning, six fish (three females and three males, $\mathrm{N}=6$ ) were sampled, and the remaining nine breeders (six females and three males) were distributed into three indoor 500-L tanks that were separated by sex and included three fish per tank. Seventy-two hours after spawning, four fish (two females and two males, $\mathrm{N}=4$ ) were sampled. Five breeders died (four females and one male). This period represents the critical period of the mortality of the matrinxã breeders [see Zanuzzo et al., 2015]. In the fish sampled, we evaluated the liver damage/integrity and complete blood counts (red blood cell, white blood cell and thrombocyte counts).

\subsection{Hormonal spawning induction and sampling}

Following initial sampling, the selected breeders were hormonally induced according to Camargo and Urbinati (2008). The females were treated (intraperitoneally) twice with carp pituitary extract (CPE, $0.5 \mathrm{mg} \mathrm{kg}^{-1}$ and $5.0 \mathrm{mg} \mathrm{kg}^{-1}$ ) dissolved in a $0.6 \%$ saline solution at $8 \mathrm{~h}$ intervals. The males were treated with a single CPE dose $\left(1.0 \mathrm{mg} \mathrm{kg}^{-1}\right)$ at the time of the second female injection. Breeders were gently netted and handled into the indoor tanks for CPE injection. The ovum and sperm were gently stripped by hand. The present study focused only on the physiological responses of breeders; thus, data on the spawning performance and hatchery were not evaluated. The fish were euthanized $\left(0.4 \mathrm{~g}^{-1} \mathrm{MS}-222\right.$, tricaine methanesulfonate; Sigma-Aldrich, São Paulo, SP, Brazil; " E10521), measured, and weighed, and blood was drawn through the caudal vessels using heparinized syringes. Thereafter, the entire liver was removed to assess tissue injuries, as described below. Whole blood was immediately used to obtain the complete blood count.

\subsection{Histological liver analysis and complete blood count}

Three portions of each liver (one from each lobe) were fixed in $10 \%$ formaldehyde (Sigma-Aldrich, São Paulo, SP, Brazil; ${ }^{\#}$ HT501128), dehydrated and embedded in Histosec blocks. Once the blocks were obtained, slices of $5-\mu \mathrm{m}$ sections from each sample were taken. An interval of $150-\mu \mathrm{m}$ between liver sections was used to avoid evaluating the same sections (lobe). From each block, six sections ( 2 for each lobe) were stained with periodic acid-Schiff (PAS) stain, and five randomly selected fields of each section were observed and photographed using a Leica DM 2500 microscope. Each randomized field corresponded to $46,800 \mu \mathrm{m}^{2}(260 \mu \mathrm{m} \times 180 \mu \mathrm{m})$ and the number of hepatocytes were counted within this respective area. Thereafter, we measured the length and width of each hepatocyte including the cytoplasm and nuclei separately. The cytoplasm and nucleus areas of hepatocytes were measured using Leica QWin image processing and analysis software.

Total blood cell counts were performed manually with an improved Neubauer hemocytometer using a formaldehyde citrate buffer as a diluent. A small drop of whole blood was smeared on a microscope slide using a smearing slide (cover glasses: $24 \times 50 \mathrm{~mm}$ ) and stained with May-Grünwald Giemsa (Rosenfeld, 1947) to determine the total red (RBC) and white blood cell (WBC) and thrombocyte counts. The blood cell types were classified following the methods of Hrubec et al. (2000) and the total cell counts were performed via the indirect method, and 2000 cells were quantified. The RBC, WBC and thrombocyte percentages were multiplied by the total blood cell count from the hemacytometer to determine the RBC, WBC and thrombocyte absolute counts.

\subsection{Statistical analysis}

The experiment was conducted with a completely randomized design. The data were analyzed for normality (Cramer-von Mises) and homoscedasticity (Brown-Forsythe). Thereafter, one-way ANOVA followed by Duncan tests were performed to examine the differences. $\mathrm{P}<0.05$ was the applied level of statistical significance in all of the analyses. The values presented in the text and figures are the means \pm 1 standard error of the mean (SEM).

\subsection{Animal welfare statement}

This research adhered to the Ethical Principles in Animal Research adopted by the National Council for the Control of Animal Experimentation - Brazil (CONCEA). The experimental procedures were approved by the Ethical Committee for Animal Research (CEUA - protocol 005019-09).

\section{Results}

All females and males successful spawned and spermiated, respectively. Between 24 and $48 \mathrm{~h}$ after spawning, one male and one female died. Between 48 and $72 \mathrm{~h}$ after spawning, three females died. At the 

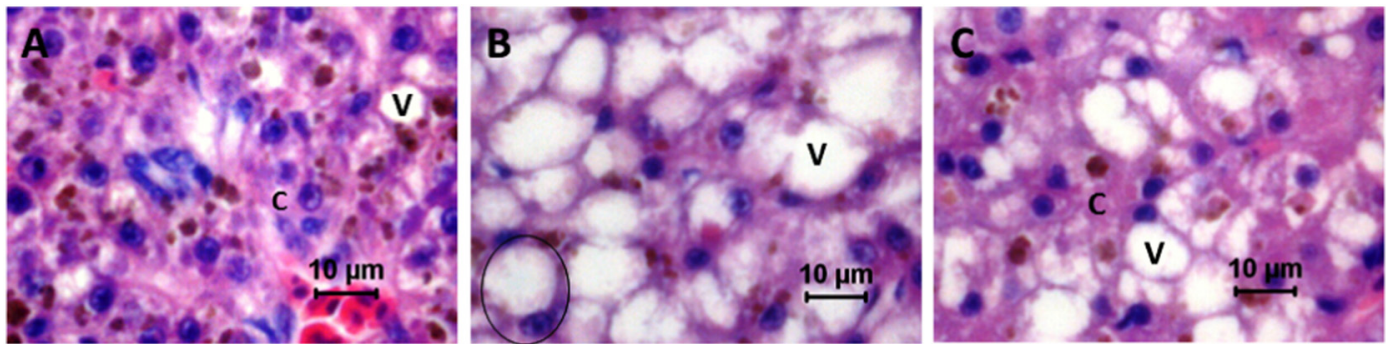

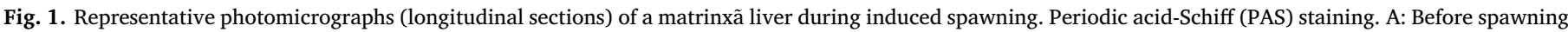
induction (initial). B: Immediately after spawning. C: $72 \mathrm{~h}$ after induced spawning. Cytoplasm (c); vacuoles (v) and vacuolated hepatocytes (O).
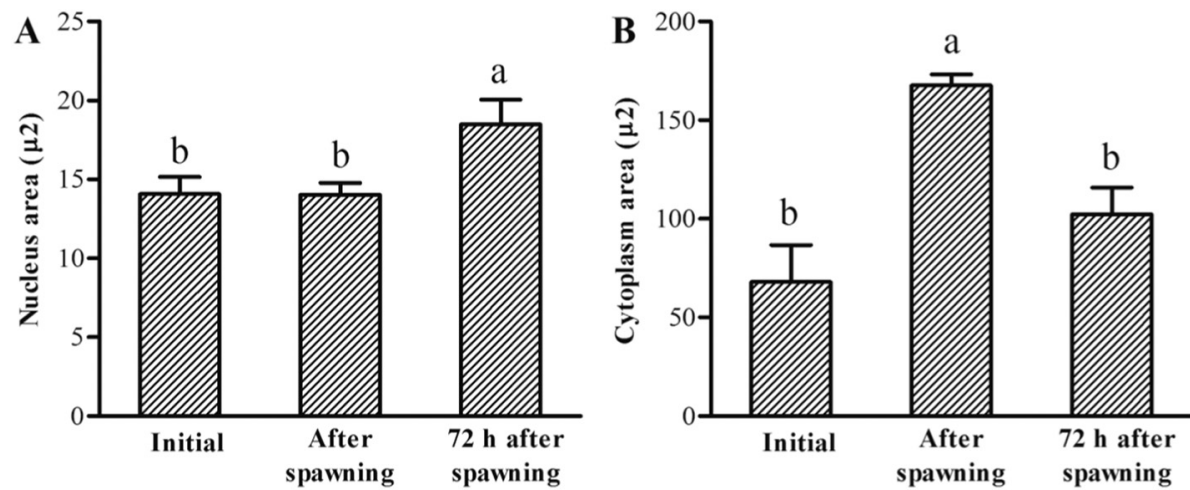

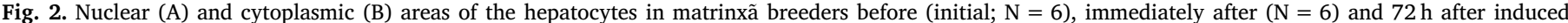
spawning $(\mathrm{N}=4)$. The different letters indicate differences among samplings $(\mathrm{P}<0.05)$. The values are presented as the means \pm 1 standard error $(\mathrm{SEM})$.
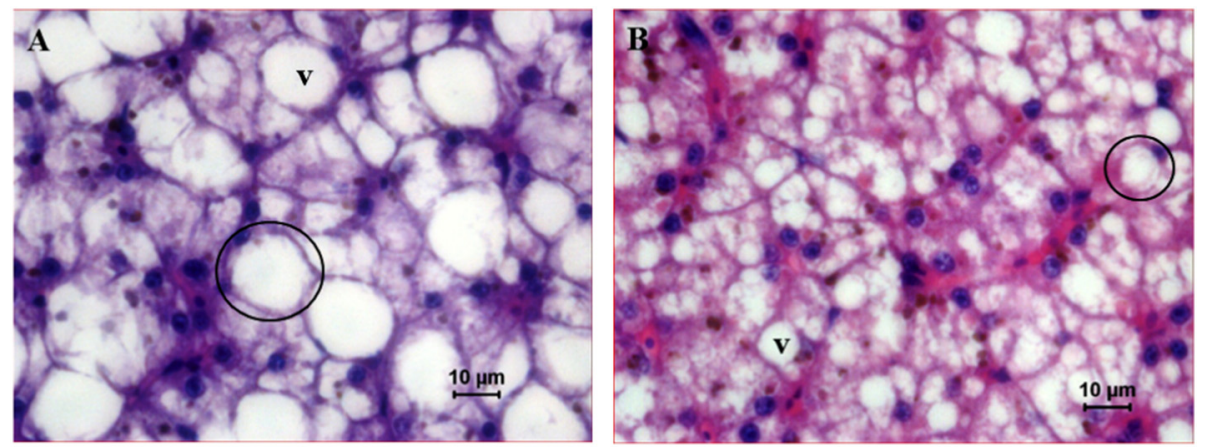

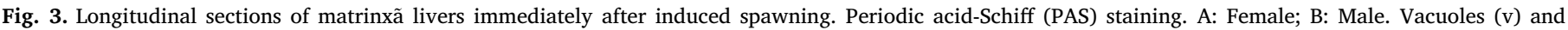
vacuolated hepatocytes $(O)$.

initial sampling, the livers of matrinxã exhibited sparse vacuoles and no significant abnormalities (Fig. 1A). However, after induced spawning, we observed an increase in cytoplasm area (Fig. 1B and 2B) that decreased $72 \mathrm{~h}$ later (Fig. 1C and 2B). At $72 \mathrm{~h}$, the nuclei of the hepatocytes were hypertrophied with pyknotic and irregular nucleus characteristics (Fig. 1C and 2A). In general, we observed hypertrophy of the hepatocytes, cellular disarray, and enlargements of the nuclei. After induced spawning, the females exhibited a greater degree of hepatocyte vacuolization than the males (Fig. 3). Immediately after induced spawning, breeders had an increase in RBC number (approx. 20,000 cells) and a decrease in WBC number (approx. 2000 cells) compared to the initial condition (Fig. 4; $\mathrm{P}<0.05$ ). The thrombocyte number was significantly lower immediately after spawning compared with the number at the initial sampling and did not return to the initial values $72 \mathrm{~h}$ later (Fig. 4).

\section{Discussion}

Several aspects of artificial reproduction in fish have been well documented such as neuroendocrine control, fecundity, gametogenesis, cryopreservation, and the efficacy of hormonal therapy, being the major concerns placed on the quality of the progeny and reproductive performance (Criscuolo-Urbinati et al., 2012; De Souza et al., 2015; Imanaga et al., 2014; Kuradomi et al., 2016; Mylonas et al., 2010; Tyler and Sumpter, 1996; Zohar et al., 2010). However, little research has been published focusing on the effects of induced spawning on breeders' health. Moreover, the deleterious effects of this process have been treated as speculative. Here, we found that the overall procedure to induced spawning including handling and injection caused a critical/ intense overload of the liver, increased red blood cell counts, and decreased white blood cell and thrombocyte counts. Taken together, these results confirm the side effects of induced spawning on breeders' and may assist to explain the mortality observed after this procedure.

Although the method applied to induce spawning in this study (hypophysation) may be primitive in its approach, it is still widely practiced in several species (Arantes et al., 2011; Criscuolo-Urbinati et al., 2012; dos Santos et al., 2013; Su et al., 2013), especially in developing countries or remote areas where access to purified hormones is 

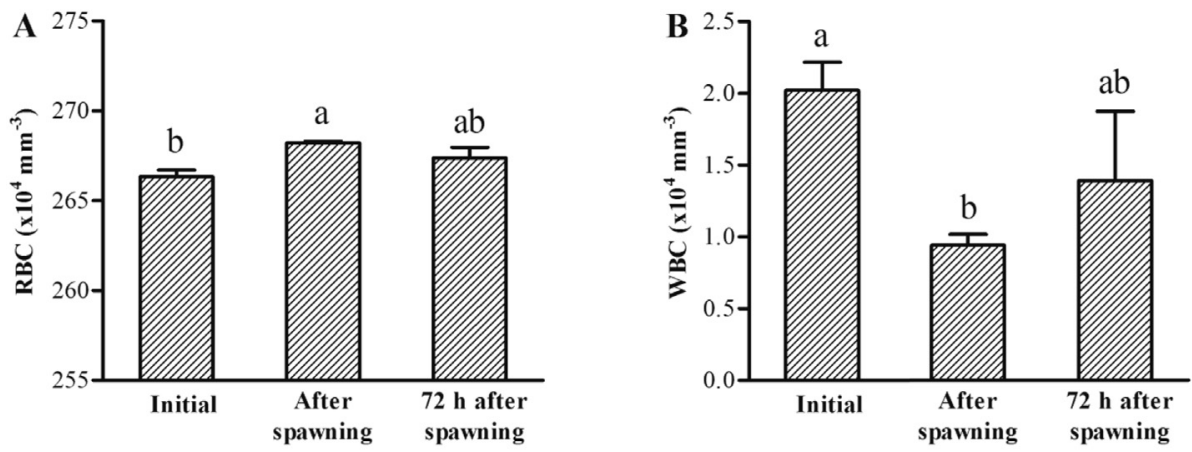

Fig. 4. Total red blood cell (RBC - A), total white blood cell (WBC - B) and thrombocyte (C) counts in the matrinxã breeders before (initial; $N=6$ ), immediately after $(\mathrm{N}=6)$ and $72 \mathrm{~h}$ after induced spawning $(\mathrm{N}=4)$. The different letters indicate differences among samplings $(P<0.05)$. The values are presented as the means \pm 1 standard error (SEM).

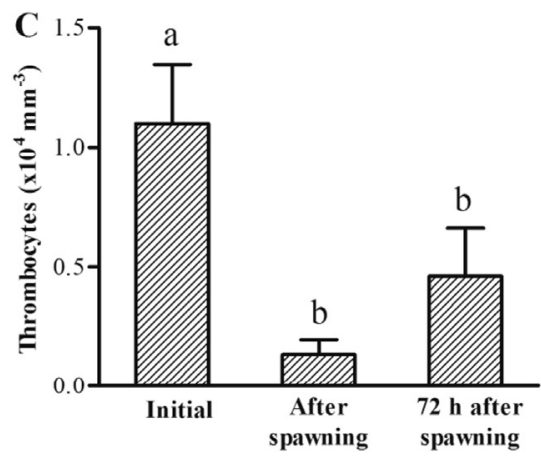

limited (Zohar and Mylonas, 2001). Moreover, while large commercialscale applications of gonadotropin-releasing hormone (GnRHa) to induce spawning have been carried out mainly in salmonids and in many other species, there is still a need for further development of speciesspecific GnRHa including the species target of this study (Mylonas and Zohar, 2001). Thus, the profile of the results found in this study could be shared with a wide range of aquaculture species.

The liver plays a key role in fish homeostasis, as we discussed previously, and injury to the liver can have severe/substantial consequences on the health status of fish (Faught and Vijayan, 2016; Karim et al., 2011; Moon, 2004). Our results revealed hypertrophy of the hepatocyte nuclei $72 \mathrm{~h}$ after induced spawning, which indicates an increase in hepatocytes activity (Haux and Norberg, 1985; Zaroogian et al., 2001). This increment was necessary to cope with the overall intense processes that occurred during spawning, such as new protein synthesis, stress responses and the clearance of the sex steroids that are secreted due to hormonal therapy stimulation and the hormones of the pituitary extract.

We observed vacuoles in the cytoplasm of the hepatocytes after induced spawning, and vacuole formation was more pronounced in females. The cytoplasm of hepatocytes contains lipid and glycogen, which are related to the normal metabolic functions. Depletions of glycogen in the hepatocytes are typically observed in stressed animals (Hinton and Laurén, 1990) because glycogen acts as a glucose reserve used to meet the increased energetic demands in such situations. We suggest that liver glycogen was intensely depleted due to the energy required for final gonad maturation as well the stress of the overall procedure of induced spawning, inducing vacuoles in the cytoplasm. Although it is unclear to what extent these alterations were caused by stress (handling) or by hormonal induction, we mainly attribute liver alterations to the administration of the pituitary extract, because: (1) Females were treated twice, whereas the males were treated only with a single dose, and this difference helps to explain the more extensive vacuolization in the females. The females might also have naturally responded more intensely than the males because the completion of final oocyte maturation demands more energy. Additionally, the pituitary extract almost instantly stimulates vitellogenesis via estradiol
(Levi et al., 2009; Palstra et al., 2010). Vitellogenesis has been shown to affect liver metabolism and increase glycogen depletion (Arukwe and Goksoyr, 2003; Schwaiger et al., 2000; Zaroogian et al., 2001). (2) The liver alterations observed in this study, including hypertrophy of the hepatocytes and enlargement of the cell nuclei accompanied by reductions in glycogen deposits, are clear symptoms of intoxication (van der Oost et al., 2003; Wolf and Wolfe, 2005). This is not likely associated with the stress of the handling during induced spawning due to the severity of liver alterations. Similar alterations are common when fish are exposed to endocrine-disrupting chemicals, xenobiotics or polluted areas (Liang et al., 2014; Zha et al., 2007; Zhang et al., 2008).

Pituitary extracts contain various compounds that affect liver function, such as growth hormone (GH), thyroid-stimulating hormone (TSH), adrenocorticotropic hormone (ACTH), follicle-stimulating hormone (FSH) and luteinizing hormone ( $\mathrm{LH})$, and thus might have caused liver alterations/intoxication. Furthermore, during induced spawning, the fish lost the natural capacity for regulation via a "feedback" mechanism because they received an unexpected "bomb" of hormones. Here, we provided evidence that the use of exogenous hormones to induce spawning impairs breeders, specifically breeders' livers, whereas this process was previously only suspected of causing side effects (Okamura et al., 2014; Zakęś and Demska-Zakȩś, 2009). As our report is a descriptive study, additional research needs to be performed to clarify/isolate the effects of the pituitary extract on the immune response and hepatic tissue. Furthermore, investigations of energy metabolism/mobilization in breeders during induced spawning are also desirable because fish in captivity need to handle with an extra amount of energy in the body that normally is used for the migration process in natural conditions. This energy reserve could also highlight the liver alterations observed here.

Induced spawning has also been shown to increase plasma glucose and decrease the leukocyte respiratory burst as consequences of the stress and to promote an intense epithelial loss [see Zanuzzo et al., 2015]. In corroborating these findings, we found that induced spawning increased the RBC and decreased the WBC and thrombocyte count, changes which are often used as indicators of stress (Barton and Iwama, 1991; Wendelaar Bonga, 1997). Indeed, during induced spawning, the 
fish were captured, transported, held, and stripped, which caused stress and impaired the immune system. However, immunosuppression may also be indirectly associated with the hormonal therapy because pituitary hormones, such as FSH and LH, stimulate the release of sex steroids, which may cause immunosuppression (Cabas et al., 2012; Watanuki et al., 2002). Taken together, these outcomes show that induced spawning causes stress, immunosuppression, and decreases physical protection (Zanuzzo et al., 2015) which jointly with a congested and imbalanced liver condition could explain the high mortality observed in this species.

Fish thrombocytes are functionally equivalent to mammalian platelets and play a significant role in hemostasis (Jagadeeswaran et al., 1999). Decreases in thrombocyte counts may be associated with the skin injuries that occur during induced spawning [see Zanuzzo et al., 2015], which suggests that the migration of bloodstream thrombocytes to the site of healing is triggered by hemostasis. However, this process could result in a net reduction in the overall thrombocyte number despite the fact that the thrombocyte numbers are typically elevated by stress (Casillas and Smith, 1977; Frisch and Anderson, 2000). Finally, although hemostasis events are well known in fish (Lang et al., 2010), to our knowledge, this study provides the first functional evidence of a reduction in circulating thrombocytes associated with the skin injuries caused by aquaculture operations.

Methodologically, studies of artificial fish reproduction in aquaculture are characterized by small sample sizes because it is difficult to obtain large numbers of breeders and facilities that can handle and maintain them (Chapman and Seidel, 2008; Migaud et al., 2013). Because of this reason, in this study it would be impractical to sample additional control groups immediately after spawning and after $72 \mathrm{~h}$ (non-injected animals or sham-injected). However, we aimed to investigate the effects of the overall handling required to induce spawning and our results clearly show and confirm that the procedure used to induce spawning using pituitary extracts impaired the health condition of the fish.

Based on the above statements and despite these methodological questions, our findings provide valuable information and are relevant to producers and researchers. They may aid in the identification of methods to ameliorate the negative effects of the procedure as well the development of further treatments for the symptoms. Moreover, our results raised important issues about induced spawning, including the following: (1) the improvement of breeder immunity/health via immunostimulants as recently investigated by Zanuzzo et al. (2015) may assist in the prevention of diseases and/or mortality; (2) the identification of the most appropriate GnRHa in a species-specific manner to avoid the pituitary extracts; (3) the establishment of minimum and optimal treatment doses for each species; (4) the development of new protocols to reduce the excessive use of exogenous hormones as suggested in some reports (Ibarra-Castro and Alvarez-Lajonchere, 2009; Kagawa et al., 2013; Kuradomi et al., 2017; Migaud et al., 2013; Okamura et al., 2014) and confirmed by Sink et al. (2010), who identified the optimal temperature for hormonal therapy; and (5) efforts to develop natural methods and spontaneous spawning. These points are crucial for the development of sustainable aquaculture (Migaud et al., 2013).

\section{Acknowledgments}

We would like to thank the staff of the Centro Nacional de Pesquisa e Conservação de Peixes Continentais (CEPTA/ICMBio) for their assistance and donation of the breeders. This research was funded by Capes (Coordenação de Aperfeiçoamento de Pessoal de Nível Superior).

\section{References}

Arantes, F.P., Santos, H.B., Rizzo, E., Sato, Y., Bazzoli, N., 2011. Influence of water temperature on induced reproduction by hypophysation, sex steroids concentrations and final oocyte maturation of the "curimata-pacu" Prochilodus argenteus (Pisces: Prochilodontidae). Gen. Comp. Endocrinol. 172, 400-408.

Arukwe, A., Goksoyr, A., 2003. Eggshell and egg yolk proteins in fish: hepatic proteins for the next generation: oogenetic, population, and evolutionary implications of endocrine disruption. Comp. Hepatol. 2, 4.

Barton, B.A., Iwama, G.K., 1991. Physiological changes in fish from stress in aquaculture with emphasis on the response and effects of corticosteroids. Annu. Rev. Fish Dis. 1, 3-26.

Cabas, I., Liarte, S., Garcia-Alcazar, A., Meseguer, J., Mulero, V., Garcia-Ayala, A., 2012 17 alpha-ethynylestradiol alters the immune response of the teleost gilthead seabream (Sparus aurata L.) both in vivo and in vitro. Dev. Comp. Immunol. 36, 547-556.

Camargo, A.C.S., Urbinati, E.C., 2008. Influence of food restriction on the reproduction and larval performance of matrinxa, Brycon amazonicus (Spix and Agassiz, 1829). Braz. J. Biol. 68, 869-873.

Casillas, E., Smith, L.S., 1977. Effect of stress on blood-coagulation and hematology in rainbow-trout (Salmo gairdneri). J. Fish Biol. 10, 481-491.

Chapman, P.L., Seidel, G.E., 2008. Experimental design, power and sample size for animal reproduction experiments. Reprod. Fert. Develop. 20, 33-44.

Criscuolo-Urbinati, E., Kuradomi, R.Y., Urbinati, E.C., Batlouni, S.R., 2012. The administration of exogenous prostaglandin may improve ovulation in pacu (Piaractus mesopotamicus). Theriogenology 78, 2087-2094.

De Souza, T.G., Hainfellner, P., Kuradomi, R.Y., Munoz, M.E., Honji, R.M., Moreira, R.G., Batlouni, S.R., 2015. Inappropriate management conditions, especially for the regressed class, are related to sperm quality in Prochilodus lineatus. Theriogenology 83, 797-807.

Donaldson, E.M., 1996. Manipulation of reproduction in farmed fish. Anim. Reprod. Sci. $42,381-392$.

dos Santos, H.B., Sampaio, E.V., Arantes, F.P., Sato, Y., 2013. Induced spawning and reproductive variables of the catfish Lophiosilurus alexandri Steindachner, 1876 (Siluriformes: Pseudopimelodidae). Neotrop. Ichthyol. 11, 607-614.

Faught, E., Vijayan, M.M., 2016. Mechanisms of cortisol action in fish hepatocytes. Comp. Biochem. Physiol. B 199, 136-145.

Frisch, A.J., Anderson, T.A., 2000. The response of coral trout (Plectropomus leopardus) to capture, handling and transport and shallow water stress. Fish Physiol. Biochem. 23, 23-34.

Haux, C., Norberg, B., 1985. The influence of Estradiol-17-Beta on the liver content of protein, lipids, glycogen and nucleic-acids in juvenile rainbow-trout, Salmo gairdnerii. Comp. Biochem. Physiol. B 81, 275-279.

Hinton, D.E., Laurén, D.J., 1990. Liver structural alterations accompanying chronic toxicity in fishes: potential biomarkers of exposure. In: McCarthy, J.F., Shugart, L.R. (Eds.), Biomarkers of Environmental Contamination. Lewis Publishers, Boca Raton, pp. 51-65.

Hrubec, T.C., Cardinale, J.L., Smith, S.A., 2000. Hematology and plasma chemistry reference intervals for cultured Tilapia (Oreochromis hybrid). Vet. Clin. Pathol. 29, 7-12.

Ibarra-Castro, L., Alvarez-Lajonchere, L., 2009. Improved induced-spawning protocol for the spotted rose snapper (Lutjanus guttatus). Isr. J. Aquac-Bamid. 61, 121-133.

Imanaga, Y., Nyuji, M., Amano, M., Takahashi, A., Kitano, H., Yamaguchi, A., Matsuyama, M., 2014. Characterization of gonadotropin-releasing hormone and gonadotropin in jack mackerel (Trachurus japonicus): comparative gene expression analysis with respect to reproductive dysfunction in captive and wild fish. Aquaculture 428, $226-235$.

Jagadeeswaran, P., Sheehan, J.P., Craig, F.E., Troyer, D., 1999. Identification and characterization of zebrafish thrombocytes. Brit. J. Haematol. 107, 731-738.

Kagawa, H., Sakurai, Y., Horiuchi, R., Kazeto, Y., Gen, K., Imaizumi, H., Masuda, Y., 2013. Mechanism of oocyte maturation and ovulation and its application to seed production in the Japanese eel. Fish Physiol. Biochem. 39, 13-17.

Karim, M., Puiseux-Dao, S., Edery, M., 2011. Toxins and stress in fish: proteomic analyses and response network. Toxicon 57, 959-969.

Khalil, N.A., Hashem, A.M., Ibrahim, A.A.E., Mousa, M.A., 2012. Effect of stress during handling, seawater acclimation, confinement, and induced spawning on plasma ion levels and somatolactin-expressing cells in mature female Liza ramada. J. Exp. Zool A. 317A, 410-424.

Kuradomi, R.Y., De Souza, T.G., Foresti, F., Schulz, R.W., Bogerd, J., Moreira, R.G., Furlan, L.R., Almeida, E.A., Maschio, L.R., Batlouni, S.R., 2016. Effects of re-stripping on the seminal characteristics of pacu (Piaractus mesopotamicus) during the breeding season. Gen. Comp. Endocrinol. 225, 162-173.

Kuradomi, R.Y., Foresti, F., Batlouni, S.R., 2017. The effects of sGnRHa implants on Piaractus mesopotamicus female breeders. An approach addressed to aquaculture. Aquac. Int. 25, 2259-2273.

Lang, M.R., Gihr, G., Gawaz, M.P., Muller, I.I., 2010. Hemostasis in Danio rerio: is the zebrafish a useful model for platelet research? J. Thromb. Haemost. 8, 1159-1169.

Levi, L., Pekarski, I., Gutman, E., Fortina, P., Hyslop, T., Biran, J., Levavi-Sivan, B., Lubzens, E., 2009. Revealing genes associated with vitellogenesis in the liver of the zebrafish (Danio rerio) by transcriptome profiling. BMC Genomics 10 (141), 1-17.

Liang, X.F., Wang, M., Chen, X., Zha, J.M., Chen, H.H., Zhu, L.F., Wang, Z.J., 2014 Endocrine disrupting effects of benzotriazole in rare minnow (Gobiocypris rarus) in a sex-dependent manner. Chemosphere 112, 154-162.

Migaud, H., Bell, G., Cabrita, E., McAndrew, B., Davie, A., Bobe, J., Herraez, M.P. Carrillo, M., 2013. Gamete quality and broodstock management in temperate fish. Rev. Aquac. 5, S194-S223.

Moon, T.W., 2004. Hormones and fish hepatocyte metabolism: "the good, the bad and the ugly!". Comp. Biochem. Physiol. B 139, 335-345.

Mylonas, C.C., Zohar, Y., 2001. Use of GnRHa-delivery systems for the control of reproduction in fish. Rev. Fish Biol. Fish. 10, 463-491.

Mylonas, C.C., Fostier, A., Zanuy, S., 2010. Broodstock management and hormonal manipulations of fish reproduction. Gen. Comp. Endocrinol. 165, 516-534. 
Okamura, A., Horie, N., Mikawa, N., Yamada, Y., Tsukamoto, K., 2014. Recent advances in artificial production of glass eels for conservation of anguillid eel populations. Ecol. Freshw. Fish 23, 95-110.

Palstra, A.P., Schnabel, D., Nieveen, M.C., Spaink, H.P., van den Thillart, G.E.E.J.M., 2010. Temporal expression of hepatic estrogen receptor 1, vitellogenin1 and vitellogenin2 in European silver eels. Gen. Comp. Endocrinol. 166, 1-11.

Rosenfeld, G., 1947. Corante pancrômico para hematologia e citologia clínica. Nova combinação dos componentes do may-grunwald e do giemsa num só corante de emprego rápido. Mem. Inst. Butantan. 20, 329-335.

Schwaiger, J., Spieser, O.H., Bauer, C., Ferling, H., Mallow, U., Kalbfus, W., Negele, R.D., 2000. Chronic toxicity of nonylphenol and ethinylestradiol: haematological and histopathological effects in juvenile common carp (Cyprinus carpio). Aquat. Toxicol. 51, 69-78.

Sink, T.D., Strange, R.J., Lochmann, R.T., 2010. Hatchery methods and natural, hormoneimplant-induced, and synchronized spawning of captive Atlantic croaker (Micropogonias undulatus) Linnaeus 1766. Aquaculture 307, 35-43.

Su, B.F., Perera, D.A., Zohar, Y., Abraham, E., Stubblefield, J., Fobes, M., Beam, R., Argue, B., Ligeon, C., Padi, J., Waters, P., Umali-Maceina, G., Chatakondi, N., Kristanto, A., Hutson, A., Templeton, C., Ballenger, J., Chaimongkol, A., Gima, A., Gima, M., Zuberi, A., Lambert, D.M., Kim, S., Mandour, M., Dunham, R.A., 2013. Relative effectiveness of carp pituitary extract, luteininzing hormone releasing hormone analog (LHRHa) injections and LHRHa implants for producing hybrid catfish fry. Aquaculture 372, 133-136.

Tyler, C.R., Sumpter, J.P., 1996. Oocyte growth and development in teleosts. Rev. Fish Biol. Fish. 6, 287-318.

van der Oost, R., Beyer, J., Vermeulen, N.P.E., 2003. Fish bioaccumulation and biomarkers in environmental risk assessment: a review. Environ. Toxicol. Pharmacol. 13, 57-149.
Watanuki, H., Yamaguchi, T., Sakai, M., 2002. Suppression in function of phagocytic cells in common carp Cyprinus carpio L. injected with estradiol, progesterone or 11-ketotestosterone. Comp. Biochem. Physiol. C 132, 407-413.

Wendelaar Bonga, S.E., 1997. The stress response in fish. Physiol. Rev. 77, 591-625.

Wolf, J.C., Wolfe, M.J., 2005. A brief overview of nonneoplastic hepatic toxicity in fish. Toxicol. Pathol. 33, 75-85.

Yaron, Z., 1995. Endocrine control of gametogenesis and spawning induction in the carp. Aquaculture 129, 49-73.

Zakẹś, Z., Demska-Zakẹś, K., 2009. Controlled reproduction of pikeperch Sander lucioperca (L.): a review. Arch. Polish Fish. 17, 153-170.

Zanuzzo, F.S., Zaiden, S.F., Senhorini, J.A., Marzocchi-Machado, C.M., Urbinati, E.C., 2015. Aloe vera bathing improved physical and humoral protection in breeding stock after induced spawning in matrinxã (Brycon amazonicus). Fish Shellfish Immun. 45, 132-140.

Zaroogian, G., Gardner, G., Horowitz, D.B., Gutjahr-Gobell, R., Haebler, R., Mills, L., 2001. Effect of 17 beta-estradiol, o,p '-DDT, octylphenol and p,p '-DDE on gonadal development and liver and kidney pathology in juvenile male summer flounder (Paralichthys dentatus). Aquat. Toxicol. 54, 101-112.

Zha, J.M., Wang, Z.J., Wang, N., Ingersoll, C., 2007. Histological alternation and vi tellogenin induction in adult rare minnow (Gobiocypris rarus) after exposure to ethynylestradiol and nonylphenol. Chemosphere 66, 488-495.

Zhang, X.Y., Zha, J.M., Li, W., Yang, L.H., Wang, Z.J., 2008. Effects of 2,4-Dichlorophenol on the expression of vitellogenin and estrogen receptor genes and physiology impairments in Chinese rare minnow (Gobiocypris rarus). Environ. Toxicol. 23, 694-701.

Zohar, Y., Mylonas, C.C., 2001. Endocrine manipulations of spawning in cultured fish: from hormones to genes. Aquaculture 197, 99-136.

Zohar, Y., Munoz-Cueto, J.A., Elizur, A., Kah, O., 2010. Neuroendocrinology of reproduction in teleost fish. Gen. Comp. Endocrinol. 165, 438-455. 